University of Wollongong

Research Online

Australian Institute for Innovative Materials -

Papers

Australian Institute for Innovative Materials

$1-1-2017$

\title{
Electrochemical biosensing strategies for DNA methylation analysis
}

Tanvir Hossain

Shahjalal University of Science and Technology

Golam Mahmudunnabi

Shahjalal University of Science and Technology

Mostafa Masud

University of Wollongong, mkm590@uowmail.edu.au

Md Nazmul Islam

Griffith University

Lezanne Ooi

University of Wollongong, lezanne@uow.edu.au

See next page for additional authors

Follow this and additional works at: https://ro.uow.edu.au/aiimpapers

Part of the Engineering Commons, and the Physical Sciences and Mathematics Commons

Research Online is the open access institutional repository for the University of Wollongong. For further information contact the UOW Library: research-pubs@uow.edu.au 


\title{
Electrochemical biosensing strategies for DNA methylation analysis
}

\begin{abstract}
DNA methylation is one of the key epigenetic modifications of DNA that results from the enzymatic addition of a methyl group at the fifth carbon of the cytosine base. It plays a crucial role in cellular development, genomic stability and gene expression. Aberrant DNA methylation is responsible for the pathogenesis of many diseases including cancers. Over the past several decades, many methodologies have been developed to detect DNA methylation. These methodologies range from classical molecular biology and optical approaches, such as bisulfite sequencing, microarrays, quantitative real-time PCR, colorimetry, Raman spectroscopy to the more recent electrochemical approaches. Among these, electrochemical approaches offer sensitive, simple, specific, rapid, and cost-effective analysis of DNA methylation. Additionally, electrochemical methods are highly amenable to miniaturization and possess the potential to be multiplexed. In recent years, several reviews have provided information on the detection strategies of DNA methylation. However, to date, there is no comprehensive evaluation of electrochemical DNA methylation detection strategies. Herein, we address the recent developments of electrochemical DNA methylation detection approaches. Furthermore, we highlight the major technical and biological challenges involved in these strategies and provide suggestions for the future direction of this important field.
\end{abstract}

\section{Disciplines}

Engineering | Physical Sciences and Mathematics

\section{Publication Details}

Hossain, T., Mahmudunnabi, G., Masud, M. Kamal., Islam, M., Ooi, L., Konstantinov, K., Hossain, M., Martinac, B., Alici, G., Nguyen, N. \& Shiddiky, M. J. A. (2017). Electrochemical biosensing strategies for DNA methylation analysis. Biosensors and Bioelectronics, 94 63-73.

\section{Authors}

Tanvir Hossain, Golam Mahmudunnabi, Mostafa Masud, Md Nazmul Islam, Lezanne Ooi, Konstantin K. Konstantinov, Md Shahriar Hossain, Boris Martinac, Gursel Alici, Nam-Trung Nguyen, and Muhammad Shiddiky 


\section{Electrochemical biosensing strategies for DNA methylation analysis}

Tanvir Hossain ${ }^{\mathrm{a} \S}$, Golam Mahmudunnabi ${ }^{\mathrm{b} \S}$, Mostafa Kamal Masud ${ }^{\mathrm{c}, \mathrm{d}, \S}$, Md. Nazmul Islam $^{\mathrm{c}, \mathrm{e}}$, Lezanne Ooi $^{\mathrm{f}}$, Konstantin Konstantinov ${ }^{\mathrm{e}}$, Md Shahriar Al Hossain ${ }^{\mathrm{d}}$, Boris Martinac ${ }^{\mathrm{g}}$, Gursel Alici $^{\text {h }}$, Nam-Trung Nguyen ${ }^{\mathrm{c}}$, Muhammad J. A. Shiddiky ${ }^{\mathrm{c}, \mathrm{e}^{*}}$

aDepartment of Biochemistry \& Molecular Biology, Shahjalal University of Science \& Technology, Sylhet-3114, Bangladesh

${ }^{b}$ Department of Genetic Engineering and Biotechnology, Shahjalal University of Science \& Technology, Sylhet-3114, Bangladesh

${ }^{\mathrm{c}}$ Queensland Micro- and Nanotechnology Centre, Griffith University, Nathan, QLD 4111, Australia

${ }^{\mathrm{d}}$ Institute for Superconducting and Electronic Materials, Australian Institute for Innovative Materials (AIIM), University of Wollongong, Squires Way, Innovation Campus, North Wollongong, NSW 2519, Australia

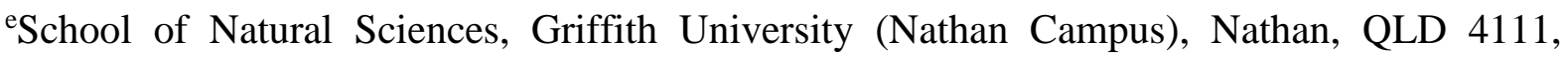
Australia

fIllawarra Health and Medical Research Institute, School of Biological Sciences, University of Wollongong, Northfields Avenue, Wollongong, NSW 2522, Australia

'Victor Chang Cardiac Research Institute, Darlinghurst, NSW 2010, Australia

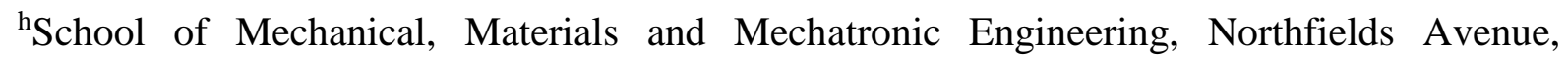
Wollongong, NSW 2522, Australia

*Corresponding Author: m.shiddiky@griffith.edu.au

$\S$ Equal contributor 


\section{Contents}

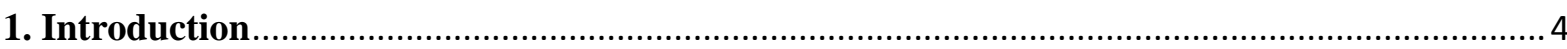

2. Diagnostic and prognostic significance of DNA methylation ...............................................

3. Electrochemical detection techniques of DNA methylation ............................................... 10

3.1. Electrochemical DNA methylation assays based on enzymatic reaction and amplifications 10

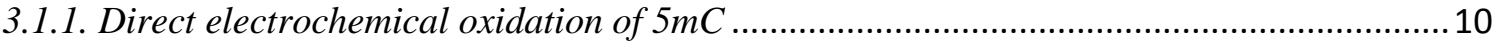

3.1.2. Restriction enzyme digestion based assays ...................................................................... 13

3.1.3. DNA methyltransferase activity based assays............................................................... 15

3.1.4. Ligase chain reaction (LCR) based strategies .............................................................. 18

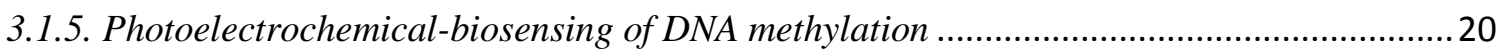

3.2. Electrochemical DNA methylation assays based on electroactive species ............................ 21

3.2.1. Semiconductors quantum dots (QDs) based assays ...................................................... 21

3.2.2. Electrochemically active ligands based methods ............................................................... 23

3.3. Electrochemical detection of DNA methylation based on affinity interaction of DNA

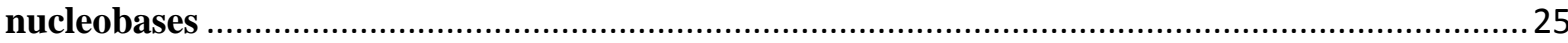

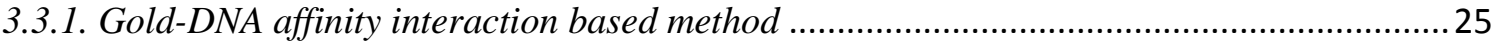

3.3.2. Graphene-DNA affinity interaction based method ......................................................... 26

3.4. Methylation assay using carbon based electrodes.............................................................. 27

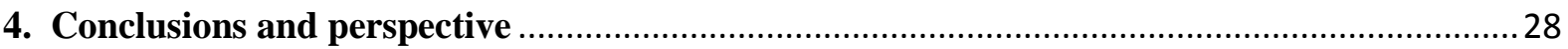

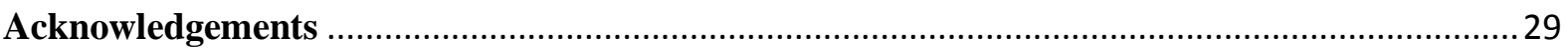

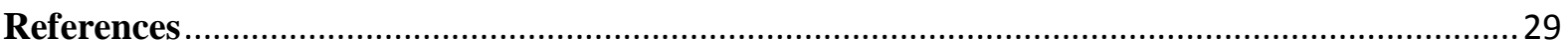




\begin{abstract}
DNA methylation is one of the key epigenetic modifications of DNA that results from the enzymatic addition of a methyl group at the fifth carbon of the cytosine base. It plays a crucial role in cellular development, genomic stability and gene expression. Aberrant DNA methylation is responsible for the pathogenesis of many diseases including cancers. Over the past several decades, many methodologies have been developed to detect DNA methylation, which range from classical molecular biology and optical approaches, such as bisulfite sequencing, microarrays, quantitative real-time PCR, colorimetry, Raman spectroscopy to the more recent electrochemistry-based approaches. Among these, electrochemistry-based approaches offer sensitive, simple, specific, faster, and cost-effective analysis of DNA methylation. Additionally, electrochemical methods are highly amenable to miniaturization and possess the potential to be multiplexed. In recent years, several reviews have provided information on the detection strategies of DNA methylation. However, to date, there has been no comprehensive one solely discussing electrochemistry based DNA methylation detection strategies. Herein, we address the recent developments of electrochemical DNA methylation detection approaches. Furthermore, we also highlight the major technical and biological challenges involved in these strategies and provide suggestions for the future direction of this important field.
\end{abstract}

Keywords: DNA Methylation, Electrochemical Detection, Hypermethylation, Hypomethylation, Global Methylation, Regional Methylation. 


\section{Introduction}

DNA methylation is the covalent addition of a methyl group to the fifth carbon of the cytosine base in the CpG dinucleotide of DNA (Bird, 2002). This important epigenetic alteration converts cytosine (C) to methylcytosine $(5 \mathrm{mC})$ keeping the original DNA sequences unchanged (Bird 2002; Tucker 2001). It plays important roles in various cellular regulatory pathways, such as gene expression and regulation, maintaining genomic stability, X chromosome inactivation and mammalian cell development (Constancia et al., 1998; Jones and Gonzalgo, 1997; Mohandas et al., 1981; Robertson and Jones, 2000). Thus, alteration in DNA methylation can result in different genetic and physiological anomalies, causing a number of diseases including neurodegenerative disorders, cardiovascular diseases and cancers (Ehrlich, 2002; Esteller, 2005; Jones and Gonzalgo, 1997).

A high level of methylated versus unmethylated DNA sequences is known as hypermethylation, whereas a low level of methylated compared to unmethylated DNA is known as hypomethylation. Early studies on DNA methylation have established a hypothesis that abberant DNA hypermethylation of the promoter region of tumor suppressor genes can initiate cancer by silencing these genes. Hypermethylation can also deactivate homebox genes, which results in abnormal morphological development, also causing cancers (Ehrlich, 2002; de Caceres et al., 2004; Jones and Gonzalgo, 1997). Hypomethylation spanning a large portion of the genome, is also actively involved in cancer development (Ehrlich, 2009). DNA hypomethylation can lead to abrupt mitotic recombination, reactivation and subsequent integration of DNA at random sites of the genome, leading to mutagenesis and genomic instability resulting in cancer (Ehrlich, 2002; Taleat et al., 2015). Due to the strong pathological effects of alterations in methylation levels, DNA methylation status has become an important biomarker for the prognosis and diagnosis of diseases, including cancers. 
Over the past few decades, considerable attention has been dedicated to develop effective methodologies to analyze DNA methylation for both research and diagnostic purposes (Herman et al., 1996; Singer-Sam et al., 1990; Hernandez et al., 2013; Taleat et al., 2015; Zhang et al., 2015b; Islam et al., 2016). The most widely used DNA methylation detection technique is bisulfite sequencing (Frommer et al., 1992). This techniques consists of bisulfite conversion of DNA followed by polymerase chain reaction (PCR) amplification and sequencing of the target methylation site. A range of modified PCR and sequencing approaches have been adopted with bisulfite conversion based approaches for DNA methylation analysis, for instance; methylation specific PCR (MSPCR) (Herman et al., 1996), quantitative MS-PCR (Hibi et al., 2011), real-time PCR (BonDurant et al., , 2011), methylight (Eads et al., 2000), methylation-sensitive high resolution melting (MS-HRM) (Wojdacz and Dobrovic, 2007), methylation-sensitive single nucleotide-primer extension (MS-SnuPE) (Gonzalgo and Jones, 1997), next generation sequencing (NGS) (Taylor et al., 2007) and reduced representation bisulfite sequencing (RRBS) (Meissner et al., 2005). Conventional analytical methods such as high performance liquid chromatography (HPLC), high performance capillary electrophoresis (HPCE) and mass spectroscopy (MS) have also been used for accurate detection of 5mC (Friso et al., 2002; Tost and Gut, 2006). Despite the accuracy of detection using HPLC, HPCE and MS methods, their routine clinical use is limited by the requirement for large amounts of input DNA, and sophisticated instruments, the longer analysis time and, low sensitivity associated with HPLC, HPCE and MS methods. In recent years, other advanced detection techniques have also been extensively developed. These include combined bisulfite restriction analysis (COBRA) (Xiong and Laird, 1997), microarray based DNA methylation profiling (Gao et al., 2005; Yan et al., 2001), surface enhanced Raman spectroscopy based assays (Wang et al., 2015a, 2016a), fluorescence based biosensors (Duan et al., 2010; Ma et al., 2015; Taleat et al., 2015; Wang et al., 2009), 
colorimetric assays (Ge et al., 2012; Wee et al., 2015a), surface plsmon resonance based assays (Carrascosa et al., 2014; Sina et al., 2014a) and quartz crystal microbalance (QCM) assay (Taleat et al., 2015).These techniques are also disadvantaged by their multi-step timeconsuming analytical procedures, the requirement for large amounts of input DNA, hazardous radiolabeling and/or expensive biological molecules, such as antibodies. Hence the development of a cost-effective, convenient and accurate method for analyzing DNA methylation status is important for medical research.

To overcome the major drawbacks of conventional methods for DNA methylation analysis, much attention has been given in developing new strategies based on electrochemistry and photoelectrochemistry (Labib et al., 2016; Lee et al., 2016; Liu et al., 2016; Taleat et al., 2015; Koo et al., 2014a; Sina et al., 2014b; Koo et al., 2014b; Dai et al., 2013; Sato et al., 2010). In comparison to the other detection approaches, electrochemistry based techniques are relatively simple, inexpensive, rapid, selective, sensitive and independent of radioactive substrates. Moreover, this technique requires only a low volume of sample. The electrochemical detection instrument is amenable to miniaturization (e.g. a small potentiostat that is only a few millimeters in size is commercially available), which is highly suitable for point-of-care settings.

In recent years, DNA methylation detection techniques have been reviewed by various groups. Taleat and colleagues reviewed recent nanotechnology based strategies (till 2014) (Taleat et al., 2015). Shanmuganathanet et al. (2013) and Zhang et al. (2015b) comprehensively discussed conventional DNA methylation techniques, whereas Hernándezet al., (2013) and Islam et al., (2016) focused solely on the PCR based and optical techniques. To the best of our knowledge, electrochemical techniques for DNA methylation analysis have not been comprehensively reviewed. Herein, we summarize the recent advances in electrochemical methylation detection strategies and discuss the challenges involved in 
electrochemical methylation sensor along with our perspectives on future progress in this field.

\section{Diagnostic and prognostic significance of DNA methylation}

As one of the most common epigenetic signalling tools, DNA methylation, mainly occurs at the cytosine bases that have been used for regulating gene expression negatively (Phillips, 2008; Qureshi et al., 2010). A family of DNA methyl transferases (Dnmts) catalyses the DNA methylation process. The de novo Dnmts, Dnmt3a and Dnmt3b are responsible for transferring a methyl group to unmodified DNA, whereas during replication, Dnmt1 known as the maintenance Dnmt, copies the methylation pattern onto the newly synthesized daughter strand from parental DNA (Fig. 1) (Moore et al., 2013).

\section{(please put Figure 1 here)}

In 1983, Feinberg and Vogenstein, first showed the relationship between DNA methylation and cancer that the cancer cell of the genomes are hypomethylated compared to their respective normal cells (Feinberg and Vogelstein, 1983). Later on, Greger et al., (1989) showed that hypermethylation also occurs at the $5^{\prime}$ end of retinoblastoma gene in tumor which is usually unmethylated in normal cells. Further, Ohtani-Fujita et al., (1993) and Herman et al., (1994) correlated the methylation of the tumour-suppressor genes with their actual silencing in cancer. Fig. 1 represents a region of a normal cell and progression on becoming a tumor cell. In tumor cells, hypomethylation occurs within the heterochromatin structure, and contributes to genomic instability and the de novo methylation in $\mathrm{CpG}$ islands, 
resulting in transcriptional silencing of growth-regulatory genes, which are common early events in tumorigenesis (Robertson, 2005).

In mammalian genomes, around $85 \% \mathrm{CpG}$ dinucleotides are distributed across the genome (scattered), while nearly $40 \%$ are in repetitive sequences. In a normal cell, these CpGs are largely hypermethylated reflecting that the genome is stable. On the other hand, these CpGs are hypomethylated in cancer cells, indicating a higher level genomic instability (Bird, 1992; Baylin and Ohm, 2006; Gaudet et al., 2003). The remaining 15\% of CpGs exist as clustered form --“CpG island”. Around $40-50 \%$ of human genes have $\mathrm{CpG}$ islands, within or near to the promoter region which reflects that DNA methylation is involved in the control of transcription of these genes (Zhu and Yao, 2009). Moore et al., (2008) showed that the hypomethylation state of circulating peripheral blood cells is tightly associated with an increase in risk of human bladder cancer, and that such cancer cells can be detected early by using the global hypomethylation state. Moreover, cancer genes are elevated with the promoter $\mathrm{CpG}$ islands containing genes and it has been associated with inactivation of tumor suppressor genes as well as oncogenic transformation. Thus aberrant methylation of $\mathrm{CpG}$ islands of genes can play roles in tumor formation and progression and, detection of such alternation in DNA methylation play significant roles in the detection of pre-malignant or early stage of disease (Montavon et al., 2012). Besides, aberrant DNA methylation provides a binary signal, where the presence of methylation indicates the presence of tumor cells (Barton et al., 2008). Caceres et al. (2004) showed that analysis of tumor-specific hypermethylation in serum DNA enhances the early detection of ovarian cancer. In this approach, hypermethylation is observed in the matched serum DNA of 41 of 50 patients (with $82 \%$ sensitivity) where 13 of 17 cases of stage I disease. In contrast, no hypermethylation was observed in normal samples collected from 40 control women (100\% specificity). The study suggested that in ovarian cancer, promoter hypermethylation is a common and early event 
that can be detected in the serum DNA from patients with stage IA or B tumors (at early localized stage of cancer).

Apart from its diagnostics roles, DNA methylation has been reported to be a good indicator to track tumor prognosis. Milani et al., (2010) first reported the prognostic roles of DNA methylation profiling for childhood acute lymphoblastic leukaemia samples. In this study, they measured DNA methylation level of 401 patients and $1320 \mathrm{CpG}$ sites that helped to classify the patients into acute lymphoblastic leukaemia sub-types. In 2005, Chan et al., (2005) reported the positive prognostic potential of DNA methylation in ovarian cancer where it was shown that hypermethylation of $18 \mathrm{~S}$ and $28 \mathrm{~S}$ rDNA methylation levels were higher in patients with long progression-free survival versus patients with short survival. Moreover, Serum RASSF1A and APC promoter 1A hypermethylation is a frequent epigenetic event in early operable gastric cancer patients (Balgkouranidou et al., 2015). They were examined 73 gastric cancer samples, of them the APC promotors for 61 patients and RASSF1A promoters for 50 patients found to be methylated around $93.6 \%$ and $68.5 \%$ respectively, but none of the healthy control samples. Also, Tang et al. (2011) reported the strong evidence of promoter hypermethylation of $S F R P 2$ in the tissue, fecal and serum samples of patients with colorectal carcinoma which was significantly linked with poor differentiation grade, lymphonode metastasis status, TNM stage and shorter overall survival. In addition, methylation of SHOX2 in lung cancers (Dietrich et al., 2012), FHIT promoter methylation in ESCC (Lee et al., 2006), PITX2 promoter methylation in prostate (Dietrich et al., 2013) and breast carcinomas (Nimmrich et al., 2008) were correlated with patient prognosis. Thus, DNA methytlation has the potential to be used as a therapeutic biomarker as well. For instance, Teodoridis et al., (2005) showed that methylation of the BRCA1, GSTP1 and MGMT genes responsible for DNA repair/drug detoxification is 
associated with improved response to chemotherapy in late stage cancer patients with epithelial tumor.

\section{Electrochemical detection techniques of DNA methylation}

In electrochemical detection of DNA methylation, generally a recognition element (e.g. antibody, enzymes, oligonucleotide probe etc.) interacts with the target sequence to selectively recognise the methylated region present in that sequence, then an electroactive signal transducer is incorporated to obtain measurable electrochemical signal to quantify the level of DNA methylation (Labib et al., 2016). Mostly, the detection is read via voltametric techniques (i.e., cyclic voltammetry (CV), linear sweep voltammetry, differential pulse voltammetry (DPV), square wave voltammetry (SWV) and stripping voltammetry), amperometry and impedimetric methods. Among these readouts, voltametric techniques, especially CV and DPV, are generally preferred (Topkaya et al. 2016). Due to the versatile ability of electrochemical sensors to detect DNA methylation with high sensitivity, over the past several years, a number of electrochemical assays have been developed. They can broadly be categorized into three main types based on their assay construction strategies: $(i)$ enzymatic reaction and amplification, (ii) electroactive species, and (iii) affinity interaction of DNA nucleobases based assays. These assays are discussed in the remaining sections of the paper.

\subsection{Electrochemical DNA methylation assays based on enzymatic reaction and amplifications}

\subsubsection{Direct electrochemical oxidation of $5 \mathrm{mC}$}


The electrochemical activity (i.e., oxidation) of $5 \mathrm{mC}$ and other nucleobases can be used to quantify the amount of $5 \mathrm{mC}$ present in a target DNA sequence. Since each base poses a definite oxidation potential at most of the conventional electrodes (i.e., carbon, gold or indium tin oxide (ITO)), the magnitude of the oxidation current of $5 \mathrm{mC}$ obtained at these electrodes gives the amount of 5mC present in a target DNA (Kato et al., 2013; Brotons et al., 2016a; Brotons et al., 2016b). The direct oxidation based quantification is suffered by the two difficulties. First, the oxidation peak potential of $\mathrm{C}$ and $5 \mathrm{mC}$ are extremely difficult to identify due to their similar molecular structure and electrochemical properties. Second, the oxidation potential of $\mathrm{T}$ is almost the same as that of $5 \mathrm{mC}$ at most of the unmodified electrode materials, which results in a great interference for the recognition and detection of 5mC (Wang et al., 2010). One of the best ways to avoid these challenges would be to develop new electrode materials with a wider potential window and higher electrode activity (Ivandini et al., 2007, Wang et al., 2013, March et al., 2015). In 2007, Einaga and colleagues reported an electrochemical method based on a boron-doped diamond (BDD) thin-film electrode, which showed a wider potential window in acid medium (i.e., low $\mathrm{pH}$ ) and successfully detected 5mC in fish sperm DNA samples. In this method, a reverse phase HPLC separation was incorporated with BDD based electrochemical detection to achieve highly resolved $5 \mathrm{mC}$ peak (Ivandini et al., 2007).

In response to achieve electrode materials with a wider potential window and higher electrode activity, Kato et al. have developed a nanocarbon film electrode where electron cyclotron resonance (ECR) was used to deposit sp2 and $\mathrm{sp} 3$ carbon mixture on a sputtered nanocarbon film to produce high electrode stability (Kato et al., 2008). In this method, a significant potential difference $(130-150 \mathrm{mV})$ between $5 \mathrm{mC}$ and $\mathrm{C}$ oxidation peaks was observed from the background-subtracted square wave voltammetric data. They also demonstrated that despite having large potential window, BDD film based electrodes 
relatively lower current responses for $5 \mathrm{mC}$ and $\mathrm{C}$ (i.e., low electrode activity). This is due to the excess amount of $\mathrm{sp}^{3}$ carbon content present on the diamond surface of BDD (DNA bases prefer to adsorb more on $\mathrm{sp}^{2}$ or $\mathrm{sp}^{2}-\mathrm{sp}^{3}$ hybridized carbon surface due to $\Pi-\Pi$ interactions) (Kato et al., 2008). However, this method was only tested in a short synthetic DNA sequence and one obvious disadvantage is the associated false background peaks resulting from the bases hidden inside the helical structure of DNA.

To reduce the background peaks, the Kato et al. proposed a unique assay for quantifying $5 \mathrm{mC}$ where DNA sequences were cut into single bases by restriction endonuclease followed by their electrochemical oxidation (Kato et al., 2011). In this assay, a long $\mathrm{CpG}$ oligonucleotide was treated with restriction endonuclease P1 which formed an identical mononucleotide 50-dNMP (20-deoxy-ribonucleoside-50-monophosphate) (Fig. 2 (i)). The direct oxidation of both 5-mC and $\mathrm{C}$ was measured on a sputtered nanocarbon film electrode using square wave voltammetry. In comparison to the other P1 digestion free sample, several-fold enhanced result was observed in terms of sensitivity and dynamic concentration range. Because it only requires simple digestion of DNA sample followed by direct electrochemical oxidation on a device that can easily be manufactured at low cost, this method has significant potential in real biological and clinical applications.

Although the direct oxidation based detection of $5 \mathrm{mC}$ at modified electrodes is inherently sensitive, they are limited by the use of background subtraction of voltammetric signal of known DNA sequences (i.e., bases) to discriminate $5 \mathrm{mC}$ peaks from that of $\mathrm{T}$. This could create a significant challenge for an unknown sample (if the DNA sequence is unknown, the quantification of $5 \mathrm{mC}$ could be influenced with the overlapped $\mathrm{T}$ ). This challenge have been addressed by using an innovative subtraction formula based on the principle of complementary base pairing in DNA sequence, as described by Wang et al. (2010). They had developed a simple method for the detection of DNA methylation using 
direct electrochemical oxidation at a multiwalled carbon nanotubes and enzyme- modified glassy carbon electrode. This method also rely on the background subtraction method. However, as the molar concentration of $\mathrm{A}$ is equal to the molar concentration of $\mathrm{T}$ (as they are complementary to each other in an unknown DNA sequence), by subtracting the voltammetric signal of A from overlapped $5 \mathrm{mC}$ and $\mathrm{T}$, the signal of $\mathrm{T}$ in a DNA sample was achieved, which allowed direct quantification of $5 \mathrm{mC}$ level in the unknown target DNA samples (see, typical responses in Fig. 2(ii)). They also extended this work to detect DNA methylation using over-oxidized polypyrrole (PPyox) directed multiwalled carbon nanotubes based electrodes (Wang et al., 2013). In recent years, in order to achieve good resolution between oxidation peaks of $5 \mathrm{mC}$ and $\mathrm{C}$, several other direct electrochemistry approaches based on graphene, graphite, and carbon nanotube-modified electrodes have also been reported (Zhang et al., 2013, Wang et al., 2015c, Wang et al., 2016b, Meng et al., 2013, Brotons et al., 2013).

\section{(Please insert Fig. 2 here)}

\subsubsection{Restriction enzyme digestion based assays}

Recent demonstrations have shown that restriction enzyme digestion can be used in electrochemical detection of DNA methylation by two ways. First, direct oxidation of restriction enzyme digested DNA bases at modified or unmodified electrodes $(e . g ., 5 \mathrm{mC}$ and other bases at nanocarbon flim electrode (Kato et al, 2011), as discussed above). Second, selective recognition of $5 \mathrm{mC}$ using methylation sensitive restriction enzymes such as HpaII and Not I (Dai et al., 2012). In these assays, as their name implies, methylation sensitive restriction enzymes cannot cleave the methylated DNA sequences, while it can fully digest the unmethylated DNA sequences (Cedar et al., 1979; Quint and Cedar, 1981). This was 
experimentally demonstrated by Hou et al. (2013), where regional methylation of p16Ink4a tumor suppressor gene was electrochemically quantified. In this method, genomic DNA was first treated with $M s e$ I restriction enzyme to get DNA fragments with cleaved ends, which were then ligated with unphosphorlylated linkers (in this case, they act as universal PCR primers). The ligated DNA was further digested with the methylation sensitive restriction endonuclease Bst UI followed by PCR amplification. This results two sets of products: $(i)$ unmethylated DNA which was not amplified due to Bst UI digestion (ii) amplified product of methylated DNA as methylated DNA was unaffected by BstUI. The amplified products were then detected by using conventional hybridization technique. CV and SWV voltammetric techniques were used to read the methylation information in the presence of a $\left[\mathrm{Co}(\text { phen })_{3}\right]\left(\mathrm{CIO}_{4}\right)_{3}$ intercalator.

One of the major complications of this method is the use of PCR amplification. In order to avoid the PCR amplification step, Dai et al. (2013) have proposed an enhanced digestion based electrochemical assay, where an oligonucleotide capture probe-functionalised gold electrodes were used to specifically hybridized both methylated and unmethylated DNA target. Methylene blue (MB), an electrochemically active dye, was then intercalated in the surface-bound dsDNAs due to the interaction between guanine residues and MB. These electrodes were then treated with the methylation sensitive restriction enzyme HpaII, which precisely cleaved the unmethylated DNA leaving $5 \mathrm{mC}$ based dsDNA unaffected, resulting in a partial loss of intercalated MB present in the unmethylated dsDNA sample. This offers a significant reduction in the voltammetric current in compare to that of the methylated counterpart. By measuring the relative current changes for methylated and unmethylated samples, the degree of DNA methylation was calculated. 


\subsubsection{DNA methyltransferase activity based assays}

As discussed in section 2, the relative level of methylation in whole genome or in a specific gene is regulated by the DNA methyltransferase (Mtase) enzyme. An overexpression of DNA MTase triggers aberrant DNA methylation, that facilitates the tumor progression through the inactivation of $\mathrm{CpG}$ island methylation mediated gene (Issa et al., 1993; Vertino et al., 1996; Robertson, 2001). For instance, in comparison to non-tumorgenic cell lines, MTase level was reported to be higher in tumorgenic cell line. Additionally, Issa et al. (1993) reported that colon tumorgenesis is also accompanied by the increased expression of this enzyme. Therefore, DNA methylation can be analyzed indirectly via assaying DNA MTase activity towards a target DNA. In recent years, much attention has been focused on developing electrochemical methods for measuring MTase activity ( $\mathrm{Li}$ et al., 2015; Liu et al., 2015; Liu et al., 2016b). For example, Liu et al., (2011) reported an electrochemical assay for the detection of DNA methylation and the activity of MTase enzyme at specific CpG methylation sites. In this method, an ferrocene acetic acid (FcA) level was used to conjugate with the hybrid dsDNA. This labeled DNA was then treated with MTase M.SsI enzyme followed by a methylation sensitive restriction enzyme HpaII endonuclease treatment. This enzyme treatments cleaved the portion of unmethylated dsDNA between adjacent cytosine causing the loss of FcA labels and offering a reduced voltammetric signal of FcA. On the other hand, since HpaII cannot exert its activity in presence of 5mC, the FcA labelled methylated dsDNA was not cleaved thereby, producing a higher voltammetric signal. Therefore, the voltammetric current generated is directly related with the level of methylation and MTase activity. Althogh this method is helpful for genomic DNA methylation analysis, the sensitivity is relatively lower compared to other reported methyltransferase assays. Furthermore, it is also limited by the use of FcA labeling. 
In an another assay, Muren et al., (2013) had used an innovative strategy with a multiplexed platform for detecting both human (Dnmt1) and bacterial (Sssl) methyltransferase activity. In this assay, a multiplexed chip consisting of sixteen electrodes was taken and divided into four quadrates. Each quadrate was modified with different DNA substrates (containing methylation site 5'-CG-3' of humans) and treated with a unique MTase enzyme and each electrode was also combined with a redox probe. The treatment of electrodes with MTase (active form) made the sites (5'-CG-3') methylated. The methylated CpG sites protect the DNA from cutting by restriction enzyme treatments. Therefore the redox signal from the probe (as DNA was intact and contained redox probe) was retained and offered signal-on state. While without the activity of MTase (due to the presence of inactive form of MTase), unmethylated DNA was easily cut down by restriction enzyme and resulting in the loss of redox probe, thereby producing lower redox signal (i.e., the near complete disappearance of redox signal). This method is able to compare up to four types of different DNA methylation targets and four MTase activities on a single platform (Fig. 3(i)).

Due to the ability of being a powerful tool of detecting aberrant DNA methylation, MTase activity based assay has been a subject of many significant studies to assist disease diagnosis and prognosis. Most of these methods were largely rely on physical (i.e., nanomaterial based), enzymatic, and non-enzymatic amplification processes (He et al., 2011; Wang et al., 2012; Baek et al., 2013; Xu et al., 2013; Wang et al., 2015d; Zhang et al., 2015a; Zhang et al., 2016; Hong et al., 2016). For example, Zhang et al. ( 2016) had developed a method for detecting DNA methylation via measuring M.SssI MTase avitivity using AuNPs as primary signal amplification element coupled with non-enzymatic hybridization chain reaction (HCR) amplification and methylation sensitive restriction enzyme digestion steps. In this method, initially AuNPs and gold electrode were modified with P3 and C1 probes respectively. A linker probe (L2) was assembled on to the electrode surface by hybridization 
between $\mathrm{C} 1$ and L2 probes, resulting a dsDNA containing a special sequence of 5' -CCGG-3'. P3 probe-modified AuNPs (DNA AuNPs) were then attached with the electrode surface via sandwich hybridization (L2 contains two complementary parts which are able to hybridize with $\mathrm{C} 1$ and P3) followed by the addition of two HCR hairpin probes (H4 and H5; H4 was designed to have a complementary region to H5 and an overhanging $5^{\prime}$ - ends to hybridize with P3). This forms a large amount of dsDNA on the electrode surface. In the subsequent step, RuHex redox molecule was used to neutralized the electrode surface (this results enormous RuHex tags on the electrode surface). Under the unmethylated condition, that is when 5'-CCGG-3' present in sandwiched dsDNA, it could be recognized, cleaved by endonuclease HapII, and further digested by exonuclease ExoIII enzymes. This results no DNA-AuNPs on the electrode surface, and hence no mimic-HCR occurred so that the voltammetric current from RuHex had no obvious effect. However, when the cleavage was blocked after the methylation of M.SssI MTase (i.e., 5'-CCGG-3' sequences is methylated), DNA-AuNPs on the Au-electrode surface could induce mimic-HCR, resulting in high DPV current.

(Please insert Fig. 3 here)

Jing et al. (2014) had reported a MB based method, where a thiolated single-stranded DNA was first assembled on to gold electrode. Complementary target DNA was then hybridized with the lower part of the surface-bound probe to form an identical dstetranucleotide target sequence for both DNA adenine methylation (Dam) MTase and methylation-resistant endonuclease Mbo I, then the upper part of the surface-bound probe was hybridized with its complementary probes that attached with AuNPs, resulting in 
enormous AuNPs amplification units onto the electrode. Since AuNPs can accommodates abundant MB and endounuclease Mbo I could not cleave the identical target sequence after it was methylated by Dam MTase, resulting in increased voltammetric current. On the contrary, the sequence without methylation could be cleaved, which would decrease the amount of adsorbed MB, causing no current response.

\subsubsection{Ligase chain reaction (LCR) based strategies}

While PCR uses two sets of primers for amplification of DNA sequences, LCR adopts four oligonucleotide probes along with thermostable ligases which are sensitive to mismatches on the 3' end of a ligating DNA probe (Barany et al., 1991a, 1991b). Generally, the readout part of target LCR products is obtained by optical methods or mass spectrometry which are limited by high running cost and complex instrumentation of the sensing method (Wee et al., 2013). In 2012, Wee et al coupled LCR with a simple and inexpensive electrochemical readout method referred to as eLCR to detect single base mismatch (Wee et al., 2012). By considering $\mathrm{C}$ to $5 \mathrm{mC}$ conversion as a single base change, Koo et al., (2014b) extended this method to detect $5 \mathrm{mC}$ in a microdevice based electrochemical assay (Fig.3(iii)). In this method, bisulfite converted and PCR amplified DNA target (where, C: methylated, T: unmethylated) was further amplified by LCR with six probes (P1-P6) to analyze the methylated DNA. In the first LCR cycle, probes complementary to C (P1) and probes complementary to $\mathrm{T}$ (P5) ligated with probe $\mathrm{P} 2$. This $\mathrm{P} 1 / \mathrm{P} 5-\mathrm{P} 2$ ligated probe then worked as a template for further LCR amplification by P3, P4 and P6 probe. The exponential LCR amplification produced two sets of ligated long knife motifs (one representing $5 \mathrm{mC}$ and the other represents the unmethylated DNA). In contrast, the un-ligated probes produced short knife motifs. These long and short knife motifs were then hybridized with P1 and P2 specific capture probes, which were pre-immobilized onto two gold electrodes. These capture probles 
selectively captured methylated and unmethlated sequences respectively. DNAzymemediated electrocatalytic reduction of hydrogen peroxide $\left(\mathrm{H}_{2} \mathrm{O}_{2}\right)$ at electrodes surfaces resulted in the relative level of methylation at a particular $\mathrm{CpG}$ site. The applicability of this assay was successfully tested in breast cancer cell lines and serum sample.

In order to detect heterogeneous methylation of epialleles of DNA strands (epialleles are the DNA strands containing a mixture of methylated, unmethylated and partially methylated regions), Wee et al., (2015b) developed an LCR based amplification method coupled electrochemical readout referred to as 'epiQ'. It has some unique advantages over existing methodologies such as $(i)$ it offers multiplexing in DNA methylation analysis, (ii) it can quantify heterogeneous methylation of epialleles of DNA strands (epialleles are the DNA strands containing a mixture of methylated, unmethylated and partially methylated regions). Previously, NGS and digital PCR were commonly used to quantify the epialleles which are limited by the high running cost and several multistep procedures. However, epiQ uniquely offers an alternative to NGS and digital PCR to quantify heterogeneous methylation of genomic DNA. In this approach, electrochemical microdevice was fabricated by photolithography. Gold electrodes surface of the microdevice was functionalized with capture probe via gold thiol self-assembling monolayer formation. Following LCR, biotin labelled oligonucleotides (specific for respective epiallele sequences) were added with the LCR products in different wells of the microdevice. After the addition of horseradish peroxidase (HRP) in each well, electrocatalaytic reduction of $\mathrm{H}_{2} \mathrm{O}_{2}$ on the modified gold microelectrode resulted in different $\mathrm{CV}$ response for different epialleles enabling the quantification of heterogeneous DNA methylation. The applicability of the epiQ was successfully tested to profile eight possible epialleles from $C D K N 2 B$ ( $p 15)$ tumor suppressor gene where it can successfully distinguish $5 \%$ and $10 \%$ of differences in epiallele levels. The analytical performance of the epiQ was also cross-validated with NGS. 


\subsubsection{Photoelectrochemical-biosensing of DNA methylation}

Generally, in photoelectrochemical approaches, a photoelectric transducers have been used to convert the DNA recognition events into a significant electrical signals and such detection mechanism relies on the recording of changed electrical signal of the employed photoactive substances by the formation of DNA duplex or DNA-recognition elements complexes. (Wu et al., 2013; Zhao et al., 2014). Compared to the conventional electrochemical readout methods, it also offers higher sensitivity due to the reduced background noise (Zhao et al., 2014). In 2008, a photoelectrochemical based strategy was developed to differentiate between $\mathrm{C}$ and $5 \mathrm{mC}$ using the photosensitizer-injected hole transfer properties of DNA on gold electrodes (Yamada et al., 2008). In this method, first, anthraquinone (AQ) photosensitizer tagged oligodeoxynucleotide (ODN) duplexes containing $5 \mathrm{mC}$ or $\mathrm{C}$ were immobilized on gold electrode. This AQ-ODN duplex DNA was then treated with methylation sensitive restriction enzymes HapII or HhaI which cleaved unmethylated DNA strands leading to the removal of photosensitizer unit from the gold electrode, thereby, reducing the photocurrent density. On the contrary, in case of $5 \mathrm{mC}$ containing duplex, restriction enzyme did not cleave the $5 \mathrm{mC}$ containing duplex retaining $\mathrm{AQ}$ which produced increased photocurrent density (Fig. 3 (ii)).

Recently another photoelectrochemical method was reported for the analysis of DNA methylation using $\mathrm{Bi}_{2} \mathrm{~S}_{3}$ nanorods as photoelectric conversion material, and $6 \times$ His and antihis tag antibody labeled recombinant methyl binding domain 1 (MBD1) protein as DNA methylation recognizing unit (Yin et al., 2014). After CpG methylated probe hybridized with its complementary and methylated $\mathrm{CpG}$ target probes on the $\mathrm{Bi}_{2} \mathrm{~S}_{3}$ nanorods and AuNPsmodified electrode, the MBD1 protein was captured through the specifical interaction 
between MBD1 protein and symmetrical cytosine methylation in $\mathrm{CpG}$ region of dsDNA. Via the immunoreaction between His tag at the end of MBD1 protein and anti-his tag antibody, anti-his tag antibody was further captured on the electrode surface. Based on the immobilization of MBD1 protein and antibody, the photoelectrochemical response decreased significantly, which was used to detect methylated DNA. In this method, $\mathrm{Bi}_{2} \mathrm{~S}_{3}$ nanorods were used as photoelectric conversion material, MBD1 protein was used as DNA methylation recognizing unit, anti-his tag antibody was used to further inhibit the photocurrent and increase the detection sensitivity. Thus, it is limited by the use to antibody to achieve amplified photoelectrochemical signal. A good photoactive materials having high photo to current conversion efficiency could help to achieve sensitive DNA methylation sensor without use of signal amplification element.

\subsection{Electrochemical DNA methylation assays based on electroactive species}

\subsubsection{Semiconductors quantum dots $(Q D s)$ based assays}

The opt-electrical characteristics, biocompatibility, sharp and well-resolved voltametric peaks obtained from metal cation released from the QDs, make QDs as a potential candidate for electroactive labeling in electrochemical DNA methylation assays (Cui et al., 2007; Resch-Genger et al., 2008; Amelia et al., 2012). Moreover, the use of anodic stripping voltammetry offers sharp stripping signals in QD-based assays, allowing sensitive detection of target and render the opportunity of multiplexing (i.e., multiple QDs can be incorporated in a single assay which can simultaneously be labelled with multiple targets for their detection) (Zhang and Wang, 2012). Generally, QD based DNA methylation detection assay is carried out by hybridizing the target DNA sequence with a surface-bound capture probe (complementary to $5 \mathrm{mC}$ containing DNA sequences), which was then further 
recognized by a QD-tagged detection probe to obtain stripping voltammetric signals. For example, Dai et al., (2013) developed a QD-based electrochemical readout method referred to as $E-m S L D R$ (methylation-specific ligation-detection reaction) for the simultaneous and multiplexed quantification of DNA methylation. In $E$ - $m s L D R$, two gene-specific methylation loci of p53 gene was selected as a target and four locus-specific sequence probes were designed, where probes 1 and 2 were labeled with QDs and probes 3 and 4 were coimmobilized magnetic bead. Bisulphite converted target gene was magnetically isolated from the sample mixture via hybridization reaction between magnetic bead-attached capture probes and target sequence followed by a magnetic isolation step. By further incubation of this sample with QD-modified probes, the QD-modified magnetic beads were added to the E. coli DNA ligase to initiate the LDR (ligation detection reaction) followed by a heating step at $90^{\circ} \mathrm{C}$. When the target is methylated, the QD-modified probes perfectly matches the pretreated p53 gene and covalently interlined to form a stable duplex, in contrast. In case of the unmethylated sample, the probes show single-base mismatch and cannot be ligated. By performing voltametric analysis of QDs attached on the magnetic beads, the methylation level of p53 gene fragment can be quantified (Fig. 4).

\section{(Please insert Fig. 4 here)}

Although E-msLDR avoids PCR amplification or restriction enzyme digestion, it is limited by several hybridization and heating steps along with longer assay time. To avoid these drawbacks, the same group has developed a modified method for quantifying methylation level in p53 gene fragment using QD barcodes (Xu et al., 2016). In this method, two dual-functional hairpin probes (HP) were designed and tagged with QDs. When target 5mC region reacted with QD-tagged HP HP loops were exposed allowing hybridization with 
targets. The target attached HPs were then magnetically isolated with another capture probefunctionalized magnetic beads. Stripping volatmmetric quantification of the QDs on isolated beads was performed to quantify the level of methylation present in the target DNA. On the other hand, when target DNA was unmethylated, HP loops will not open causing no hybridization among target and magnetic beads, resulting no stripping signals.

\subsubsection{Electrochemically active ligands based methods}

In recent years, a number of electroactive ligands or molecules (e.g., methylene blue, triphenylmethane, etc.) have been used in developing various electrochemical methylation assays (Dai et al., 2012; Sato et al., 2010, Tanaka et al., 2007). In 2007, Okamoto and colleagues reported a bisulfite-free and PCR-free method for the detection of DNA methylation using a tag-attachable bipyridine electroactive ligand. A bipyridine derivative with a tag-attachable amino linker at $\mathrm{C} 4$ position was initially synthesized which was then used to directly complexed with $5 \mathrm{mC}$ residue in a reaction mixture containing potassium osmate and potassium hexacyanoferrate (III). The succinimidyl esters of functional labeling units were then attached to the bipyridine ligand fixed on the $5 \mathrm{mC}$. This allows them to detect the target 5mC in DNA electrochemically, where a capture probe attached electrode was used to selective hybridized the target, and read the methylation level via SWV. Faradic impedance spectroscopic readout in the presence of $\left[\mathrm{Fe}(\mathrm{CN})_{6}\right]^{3-14-}$ has also been used in this system to detect $5 \mathrm{mC}$, where the ligand attached-5mC showed a relatively higher interfacial electron-transfer resistance compare to those obtained at the unmethylated and non-target samples.

Sato and colleagues explored the use of ferrocenylnaphthalene diimide (FND) derivatives in detecting 5mC (Sato et al., 2006, 2010, 2012, 2014). These derivatives can intercalate into dsDNA by a threading intercalation mode at every two base pairs, resulting in 
the arrangement of many ferrocene molecules in the major and minor grooves of dsDNA. This would offer a significant enhancement in electrochemical signal (Sato et al., 2010, 2012). In 2006, they demonstrated that use of FND in 5mC detection improves the electrochemical response by stabilizing the dsDNA and producing more charge transfer through dsDNA (i.e., duplex-mediated charge transport). In this method, a 20bp long methylated promoter region of p16Ink4a gene containing two $5 \mathrm{mC}$ at the $3^{\prime}$ end of the sequence was selected as target. After bisulfite treatment, target region of gene was amplified by the PCR with the methylation-specific primers. The PCR-amplified samples were then hybridized with two DNA probes pre-immobilised on to a chip array containing 25 gold electrodes. During hybridization, methylated specific probe was fully matched with methylated sequence, whereas other showed mismatch with it. Under optimal conditions, both probes formed duplexes with the target DNA sequence. However, mismatched duplex would be less stable compared to the matched duplex containing $5 \mathrm{mC}$. This was detected by measuring the voltammetric currents in the presence of FND complexes, where matched duplex DNA produced significantly larger current in compare to that of the mismatched duplex. This method was further extended to detect methylation of CDH4 and hTERT genes (Sato et al., 2010; Sato et al., 2014). Although, these FND-based electrochemical hybridization methods showed their significant potential in detecting $5 \mathrm{mC}$, they need prior knowledge of the target DNA sequences, and therefore is not suitable for the analysis of samples containing unknown sequences.

As discussed briefly in Section 3, methylene blue is one of the widely used electroactive indicators for the analysis of various types of DNA targets including DNA methylation, point mutation and DNA lesion (Boon et al., 2000; Kelley et al., 1999; Jing et al., 2014). Generally, in methylation assays, MB attach either intercalatively to the hybridized dsDNA or covalently to the reporter probes (Dai et al., 2012; Hou et al., 2003; Jing et al., 
2014). Among other electroactive redox molecules, $\left[\mathrm{Ru}\left(\mathrm{NH}_{3}\right)_{6}\right]^{3+}$ has also been used in electrochemical methylation assays. Wang et al., (2012) has developed an electrochemical assay for DNA methylation analysis of p53 gene containing two CpG sites (Wang et al., 2012). In this assay, the bisulfite-treated target gene was hybridized with a complimentary peptide nucleic acid (PNA) probe pre-immobilized onto an AuNPs-modified GCE. When target is fully methylated, it completely hybridized with the surface-bound PNA probe making a duplex. $\left[\mathrm{Ru}\left(\mathrm{NH}_{3}\right)_{6}\right]^{3}$ then electrostatically attached to the negatively charged backbone of p53, making a PNA-methylated p53-[Ru( $\left.\left(\mathrm{NH}_{3}\right)_{6}\right]^{3}$ complex, which produced enhanced voltammetric current. However, if the $p 53$ is unmethylated, two C converted to $\mathrm{U}$ via bisulfite treatment, resulting two bases mismatches with the PNA probe. Thus, the a PNA-unmethylated $\mathrm{p} 53-\left[\mathrm{Ru}\left(\mathrm{NH}_{3}\right)_{6}\right]^{3}$ hybridization efficiency becomes relatively low which resulted less voltammetric current.

\subsection{Electrochemical detection of DNA methylation based on affinity interaction of DNA nucleobases}

\subsubsection{Gold-DNA affinity interaction based method}

The adsorption between gold and "native" DNA has been regarded as 'complex', 'non-specific' and 'difficult to control'. Mirkin and Rothberg groups have performed several key experimental and fundamental studies and reported that adsorption of DNA towards gold is sequence dependent and follows a definite adsorption trend of adenine $(\mathrm{A})>$ cytosine $(\mathrm{C})>$ guanine (G) > thymine (T) (Demers et al., 2000; Demers et al., 2002; Kimura-Suda et al., 2003; Li and Rothberg, 2004; Ostblom et al., 2005; Zhang et al., 2012). Since then base dependent DNA adsorption emerged as one the most promising solutions to achieve controlled immobilization of unmodified DNA probes onto gold surfaces. Because this 
adsorption is highly sequence (base) dependent, it can also be used to distinguish two different DNA sequences (e.g., bisulphite treated sequences representing methylated and unmethylated DNA. However, this phenomenon has not been taken into consideration to analyze DNA methylation until 2014. In 2014, Sina et al. (2014b) reported an electrochemical method for quantifying $5 \mathrm{mC}$ using different affinity interaction between DNA bases and unmodified gold electrodesreferred to as eMethylsorb (Fig. 5 (i)). In eMethylsorb, after bisulfite treatment and asymmetric PCR amplification steps, target methylated DNA become guanine-enriched, while unmethylated sample become adenine enriched. Since DNA-gold affinity interaction follows the trend, A $>C>G>T$ the adenineenriched unmethylated DNA leads to a larger level of adsorbed DNA on the electrode in comparison to the guanine-enriched methylated DNA. This provides less Faradaic current due to the strong coulombic repulsion between $\left[\mathrm{Fe}(\mathrm{CN})_{6}\right]^{3-}$ and negatively charged adenine enriched DNA strands. This method has been used to distinguish methylated and unmethylated epigenotypes at single $\mathrm{CpG}$ resolution.

\subsubsection{Graphene-DNA affinity interaction based method}

More recently, Hakim et al. (2016) developed a unique electrochemical method for the quantification of methylation level in samples taken from oesophageal cancer tissues. The underlying principle of this method was the different affinity interaction between DNA bases and graphene surface. The different affinity interaction can be explained by considering the polarisabilities of the individual nucleobases. Among all nucleobases, G and A with their five- and six-membered rings possess the largest polarisabilities, whereas other bases with only six-membered rings exhibit lower polarisabilities. Additionally, G with its doublebonded oxygen atom possess a larger polarisability than A. Since the van der Wall (vdW) energy is directly proportional to the interacting nucleobases, Scheicher (Gowtham et al., 
2007) and Rao (Varghese et al., 2009) proposed that vdW interaction is indeed the main driving force for the adsorption of nucleobases onto the graphene and follows the adsorption trend as $\mathrm{G}>\mathrm{A}>\mathrm{T}>\mathrm{C}$. Bisulfite converted and G-enriched sequences are directly adsorbed on the graphene modified electrode, which leads to a larger amount of the adsorption on to the electrode in comparison to the A-enriched unmethylated DNA. Therefore, methylated DNA will give less electrochemical readout (due to more adsorption of guanine on graphene modified electrode) compared to unmethylated DNA. They successfully tested the method in a panel of cancer cell lines and patient samples derived from oesophageal squamous cell carcinoma to detect $F A M 134 B$ promoter gene methylation.

The simplicity and functionality of affinity interaction based methods involve (i) the use of differential adsorption affinity of DNA nucleotides as a tool for cancer biomarker detection, (ii) adoption of a simple and inexpensive read-out (i.e., electrochemistry), (iii) demonstration of an simple and rapid detection method without the use of complicated surface modifications, and (iv) potential multiplexing capability. Since the this approach distinguishes between methylated and unmethylated DNA depending on the base changes generated at the $\mathrm{CpG}$ sites by bisulphite treatment, they assumed that that it may also find its application in detecting global hypomethylation.

\subsection{Methylation assay using carbon based electrodes}

There has been an increasing interest on using carbon based working electrodes in the electrochemical assay for detecting DNA methylation. Several studies have been carried out to detect $5 \mathrm{mC}$ on nanocarbon-film electrodes by optimizing the assay condition and surface modification of the electrode (Goto et al., 2010; Kato et al., 2008; Yanagisawa et al., 2015). It has been shown that assay performance of nanocarbon-film electrode based strategies are highly relied on the physical properties of the electrodes and their functionalization. More 
recently, carbon based GCE and screen-printed electrodes have also been successfully modified with conducting polymer, carbon nanotubes, nanocomposite and nanostructured gold materials used to analyze DNA methylation (Wang et al., 2016b; Zhu et al., 2015; Wang et al., 2013; Serpi et al., 2013; Zhu et al., 2015; Daneshpour et al., 2016; He et al., 2011). For example, Daneshpour et al., (2016) chemically modified screen printed carbon electrode surfaces with $\mathrm{Fe}_{3} \mathrm{O}_{4} / \mathrm{N}$-trimethyl chitosan/gold nanocomposite and polythiophene to quantify $5 \mathrm{mC}$ in a RASSF1A tumor suppressor gene. In this method, the nanocomposite $\mathrm{Fe}_{2} \mathrm{O}_{3} / \mathrm{TMC} / \mathrm{Au}$ works as tracing label of the DNA probe which increases the electrochemical readout by several fold due to the presence of AuNPs.

\section{Conclusions and perspective}

We have reviewed the current electrochemical strategies for DNA methylation analysis. We have also pointed out the methodological shortcomings of these strategies. The diagnostic and prognostic significance of $5 \mathrm{mC}$ have also been discussed. The importance of direct detection of $5 \mathrm{mC}$ either by oxidizing the nucleobases or by directly adsorbing the target onto the gold or graphene electrodes, which could significantly simply the assay fabrication by avoiding the multistep surface functionalization process, has also been discussed. It is now apparent that many traditional electrode have been modified with various nanomaterials to achieve improved analytical performance. It is also apparent that most of the methylation detection methods described here have been developed as a proof of concept study. They are yet to be tested how they perform in real, heterogeneous clinical samples which are far more complex and difficult to analyse. However, the advent of the recent breakthroughs in electrochemical detection approaches for DNA methylation is a reflection of intense focus and endeavor of the researchers in this field.

Though electrochemical sensors have potential to be used as a point-of-care tool in clinics for DNA methylation analysis, significant challenges are still required to be addressed 
before they can be used in clinics. We believe that a fully automated electrochemical sensor that can work with no human intervention is required for their routine methylation analysis studies in clinics. Furthermore, innovative and real-time sampling strategies are needed to avoid false negative bias (i.e., small volume of blood taken from a cancer patient may not carry the necessary methylation markers and will result in a false negative result). Though there are major challenges which need to be addressed, we foresee that in near future these proof-of-concept studies will be translated in both clinical and research platforms for analyzing DNA methylation.

\section{Acknowledgements}

This work was supported by the higher degree research scholarship (Matching Scholarship and IPTA award to M.K.M) from University of Wollongong, NHMRC CDF (APP1088966 to M.J.A.S.) and higher degree research scholarships (GUIPRS and GUPRS scholarships to. M.N.I) from the Griffith University.

\section{References}

Amelia, M., C Lincheneau, C., Silvi, S., Credi, A., 2012. Chem. Soc. Rev. 41, 5728-5743.

Baek, S., Won, B.Y., Park, K.S., Gyu Park, H.G., 2013. Biosens. Bioelectron. 49, 542-546.

Balgkouranidou, I., Matthaios, D., Karayiannakis, A., Bolanaki, H., Michailidis, P., Xenidis, N., et al., 2015. Mutat. Res., 778, 46-51.

Barton, C.A., Hacker, N.F., Clark, S.J., O'Brien, P.M., 2008. Gynecol. Oncol. 109, 129-139.

Baylin, S. B., Ohm, J. E., 2006. Nat. Rev. Cancer 6 (2), 107-116.

Bird, A., 2002. Genes Dev. 16 (1), 6-21.

BonDurant, A.E., Huang, Z., Whitaker, R.S., Simel, L.R., Berchuck, A., Murphy, S.K., 2011. Gynecol. Oncol. 123 (3), 581-587. 
Boon, E.M., Ceres, D.M., Drummond, T.G., Hill, M.G., Barton, J.K., 2000. Nature Biotechnol. 18(10), 1096-1100.

Brotons, A., Mas, L.A., Metters, J.P., Banks, C.E., Iniesta, J., 2013. Analyst 138, 5239

Brotons, A., Arán-Ais, R.M., Feliu, J.M., Montiel, V., Iniesta, J., Vidal-Iglesias, et al., 2016a. Electrochem. Commun. 65, 27-30.

Brotons, A., Vidal-Iglesias, F.J., Solla-Gullón, J., Iniesta, J., 2016b. Anal. Methods 8, 702715.

Caceres, I.D., Battagli C, Esteller M, Herman, J.G., Dulaimi, E., Edelson, M.I., Bergman, C., Ehya, H., Eisenberg, B.L., Cairns, P., 2004. Cancer Res. 64(18), 6476-6481.

Carrascosa, L.G., Sina, A.A., Palanisamy, R., Sepulveda, B., Otte, M.A., Rauf, S., Shiddiky M.J.A., Trau, M., 2014. Chem. Commun. 50 (27), 3585-3588.

Cedar, H., Solage, A., Glaser, G. and Razin, A., 1979. Nucleic Acids Res. 6 (6), 2125-2132.

Chan, M.W., Wei, S.H., Wen, P., Wang, Z., Matei, D.E., Liu, J.C., et al., 2005. Clin. Cancer Res. 11(20), 7376-7383.

Cui, R., Pan, H-C., Zhu, J-J., Chen, H-Y., 2007. Anal. Chem. 79 (22), 8494-8501.

Dai, Z., Hu, X., Wu, H., Zou, X., 2012. Chem. Commun. 48 (12), 1769-1771.

Dai, Z., Cai, T., Zhu, W., Gao, X., Zou, X., 2013. Chem. Commun. 49 (19), 1939-1941.

Daneshpour, M., Moradi, L.S., Izadi, P., Omidfar, K., 2016. Biosens. Bioelectron. 77, 10951103.

de Caceres, I.I, Battagli, C., Esteller, M., Herman, J.G., Dulaimi, E., Edelson, M.I., et al., 2004. Cancer Res. 64 (18), 6476-6481.

Demers, L.M., Mirkin, C.A., Mucic, R.C., Reynolds, R.A., Letsinger, R.L., Elghanian, R., et al., 2000. Anal. Chem. 72 (22), 5535-5541. 
Demers, L.M., Östblom, M., Zhang, H., Jang, N.-H., Liedberg, B., Mirkin, C.A., 2002. J. Am. Chem. Soc. 124 (38), 11248-11249.

Dietrich D., Hasinger, O., Liebenberg, V., Field, J.K., Kristiansen, G., Soltermann, A., 2012. Diagn. Mol. Pathol., 21 (2), 93-104.

Dietrich D., Hasinger, O., Banez, L.L., Sun, L., van Leenders, G.J., Wheeler, T.M., et al., 2013. J. Mol. Diagn. 15 (2), 270-279.

Drummond, T.G., Hill, M.G., Barton, J.K., 2003. Nat. Biotechnol. 21, $1192-1199$.

Duan, X., Liu, L., Feng, F., Wang, S., 2010. Acc. Chem. Res. 43(2), 260-270.

Eads, C.A., Danenberg, K.D., Kawakami, K., Saltz, L.B., Blake, C., Shibata, D., Danenberg, P.V., Laird, P.W., 2000. Nucleic Acids Res. 28 (8), e32-00

Ehrlich, M., 2002. Oncogene 21 (35) 5400-5413.

Ehrlich, M., 2009. Epigenomics 1 (2) 239-259.

Esteller, M., 2005. Curr. Opin. Oncol. 17 (1), 55-60.

Feinberg, A. P., \& Vogelstein, B., 1983. Nature 301 (5895), 89-92.

Friso, S., Choi, S.-W., Dolnikowski, G.G., Selhub, J., 2002. Anal. Chem. 74 (17), 4526-4531.

Frommer, M., McDonald, L.E., Millar, D.S., Collis, C.M., Watt, F., Grigg, G.W., et al., 1992. Proc. Natl. Acad. Sci. 89 (5) 1827-1831.

Gao, L., Cheng, L., Zhou, J.N., Zhu, B.L., Lu, Z.H., 2005. Colloids Surf., B, 40 (3), 127-131.

Gaudet, F., Hodgson, J.G., Eden, A., Jackson-Grusby, L., Dausman, J., Gray, J.W., et al. 2003. Science 300 (5618), 489-492.

Ge, C., Fang, Z., Chen, J., Liu, J., Lu, X., Zeng, L., 2012. Analyst 137 (9), 2032-2035.

Gonzalgo, M.L., Jones, P.A., 1997. Nucleic Acids Res. 25 (12), 2529-2531.

Goto, K., Kato, D., Sekioka, N., Ueda, A., Hirono, S., Niwa, O., 2010. Anal. Biochem. 405 (1), 59-66.

Gowtham, S., Scheicher, R.H., Ahuja, R., Pandey, R., Karna, S. P., 2007. Phys. Rev. B 76 (3), 033401.

Greger, V., Passarge, E., Höpping, W., Messmer, E., \& Horsthemke, B., 1989. Hum. 
Genet. 83 (2), 155-158.

Haque, M.H., Gopalan, V., Yadav, S., Islam, M.N., Eftekhari, E., Li, Q., Carrascosa, L.G., Nguyen, N.T., Lam, A.K. and Shiddiky, M.J., 2017. Biosens. Bioelectron. 87, 615-621.

He, X., Su, J., Wang, y., Wang, k., Ni, X., Chen, Z., 2011. Biosens. Bioelectron. 28 (1), 298 303.

Herman, J. G., Latif, F., Weng, Y., Lerman, M. I., Zbar, B., Liu, S., \& Linehan, W. M., 1994. Proc. Nat. Acad. Sci. 91 (21), 9700-9704.

Herman, J.G., Graff, J.R., Myohanen, S., Nelkin, B.D., Baylin, S.B., 1996. Proc. Natl. Acad. Sci. 93 (18), 9821-9826.

Hernandez, H.G., Tse, M.Y., Pang, S.C., Arboleda, H., Forero, D.A., 2013. Biotechniques 55 (4), 181-197.

Hibi, K., Goto, T., Shirahata, A., Saito, M., Kigawa, G., Nemoto, H., Sanada, Y., 2011. Cancer Lett. 311 (1), 96-100.

Hong, L., Jing Wan, J., Zhang, X., Wang, G.F., 2016. Talanta 152, 228-235.

Hou, P., Ji, M., Ge, C., Shen, J., Li, S., He, N., Lu, Z., 2003. Nucleic Acids Res. 31 (16), e92. Islam, M. N., Yadav, S., Haque, M. H., Munaz, A., Islam, F., Hossain, M. S. A., Gopalan, V., Lam, A K., Nguyen, N-T., Shiddiky, M. J. A., 2016. Biosens. Bioelectron. doi: http://dx.doi.org/10.1016/j.bios.2016.10.034.

Ivandini, T.A., Hondac, K., Rao, T.N., Fujishima, A., Einaga, Y., 2007. Talanta 71 (2), 648655.

Issa, J.P.J., Vertino, P.M., Wu, J., Sazawal, S., Celano, P., Nelkin, B.D., Hamilton, S.R., et al., 1993. J. Natl. Cancer Inst. 85(15), 1235-1240.

Jing, X., Cao, X., Wang, L., Lan, T., Li, Y., Xie, G., 2014. Biosens. Bioelectron. 58, 40-47. Jones, P.A., Gonzalgo, M.L., 1997. Proc. Natl. Acad. Sci. 94 (6), 2103-2105.

Jones, P.A., Baylin, S,B., 2002. Nat Rev. Genet. 3, 415-28. 
Niwa

Kelley, S.O., Boon, E.M., Barton, J.K., Jackson, N.M., Hill, M.G., 1999. Nucleic Acids Res. 27 (24), 4830-4837.

Kimura-Suda, H., Petrovykh, D.Y., Tarlov, M.J., Whitman, L.J., 2003. J. Am. Chem. Soc. 125 (30), 9014-9015.

Koo, K.M., Sina, A.A., Carrascosa, L.G., Shiddiky, M.J.A., Trau, M., 2014a. Analyst 139 (23), 6178-6184.

Koo, K.M., Wee, E.J., Rauf, S., Shiddiky, M.J.A., Trau, M., 2014b. Biosens. Bioelectron. 56, 278-285.

Koo, K.M., Sina, A.A.I., Carrascosa, L.G., Shiddiky, M.J.A., Trau, M., 2015. Anal. Methods 7 (17), 7042-7054.

Labib, M., Sargent, E.H., Kelley, S.O., 2016. Chem. Rev. 116 (16), 9001-9090.

Lee, E.J., Lee, B.B., Kim, J.W., Shim, Y.M., Hoseok, I., Han, J., Cho, E.Y., et al., 2006. Eur.J. Cancer, 42 (7), 972-980.

Lee, J., Yoshidab, W., Abea, K., Nakabayashic, K., Wakedad, H., Hatac, K. et al., 2016. Biosens. Bioelectron. doi: http://dx.doi.org/10.1016/j.bios.2016.09.060

Li, H. and Rothberg, L., 2004. Proc. Natl. Acad. Sci. 101 (39), 14036-14039.

Li, W., Liu, X., Hou, T., Li, H., Li, F., 2015. Biosens. Bioelectron. 70, 304-309.

Liu, S., Wu, P., Li, W., Zhang, H., Cai, C., 2011. Chem. Commun. 47, 2844-2846.

Liu, S., Zhanga, X., Zhao, K., 2016a. J. Electroanal. Chem. 773, 63-68.

Liu, P., Liu, M., Yin, H., Zhou, Y., Ai, S., 2015. Sensor. Actuator B-Chem. 220, 101-106.

Liu, P., Wang, D., Zhou, Y., Wang, H., Yin, H., Ai, S., 2016b. Biosens. Bioelectron. 80, 7478.

Ma, Y., Zhang, H., Liu, F., Wu, Z., Lu, S., Jin, Q., Zhao, J., Zhong, X., Mao, H., 2015. Nanoscale 7 (41), 17547-17555. 
March, G., Nguyen, T.D. \& Piro, B., 2015. Biosensors. 5 (2), 241-275.

Meng, X., Xu, Z., Wang, M., Yin, H., Ai, S., 2013. Electrochim. Acta 95, 200- 204.

Milani, L., Lundmark, A., Kiialainen, A., Nordlund, J., Flaegstad, T., Forestier, E., et al., 2010. Blood 115 (6), 1214-1225.

Mohandas, T., Sparkes, R.S., Shapiro, L.J., 1981. Science 211 (4480), 393-396.

Montavon, C., Gloss, B. S., Warton, K., Barton, C. A., Statham, A. L., Scurry, J. P.\& Hacker, N. F. 2012. Gynecol. Oncol. 124 (3), 582-588.

Moore, L. E., Pfeiffer, R. M., Poscablo, C., Real, F. X., Kogevinas, M., Silverman, D., et al., 2008. Lancet Oncol. 9 (4), 359-366.

Moore, L. D., Le, T., \& Fan, G. 2013. Neuropsychopharmacology 38 (1), 23-38.

Muren, N.B., Barton, J.K., 2013. J. Am. Chem. Soc. 135 (44), 16632-16640.

Nimmrich, I., Sieuwerts, A.M., Meijer-van Gelder, M.E., Schwope, I., Bolt-de Vries, J., et al., 2008. Breast Cancer Res. Treat. 111 (3), 429-437.

Ohtani-Fujita, N., Fujita, T., Aoike, A., Osifchin, N. E., Robbins, P. D., \& Sakai, T., 1993. Oncogene 8.

Ostblom, M., Liedberg, B., Demers, L.M., Mirkin, C.A., 2005. J. Phys. Chem. B 109 (31), $15150-15160$.

Park, J. S., Goo, N-I., Dong-Eun Kim, D-E., 2014. Langmuir 30 (42), 12587-12595

Phillips, T. 2008. Nature Education, 1(1), 116. Accessed on October 26 at http://www.nature.com/scitable/topicpage/the-role-of-methylation-in-gene-expression-1070 Quint, A., Cedar, H., 1981. Nucleic Acids Res. 9 (3), 633-646.

Qureshi, S. A., Bashir, M. U., \& Yaqinuddin, A., 2010. Int. J. Surg. 8 (3), 194-198.

Robertson, K.D., Jones, P.A., 2000. Carcinogenesis 21 (3), 461-467.

Robertson, K.D., 2001. Oncogene 20, 3139-3155. 
Robertson, K. D. 2005. Nat. Rev. Genet. 6 (8), 597-610.

Sato, S., Hokazono, K., Irie, T., Ueki, T., Waki, M., Nojima, T., Kondo, 2006. Anal. Chim. Acta 578, 82-87.

Sato, S., Tsueda, M., Takenaka, S., 2010. J. Organomet. Chem. 695 (15), 1858-1862.

Sato, S., Tsueda, M., Kanezaki, Y., Takenaka, S., 2012. Anal. Chim. Acta 715, 42-48.

Sato, S., Saeki, T., Tanaka, T., Kanezaki, Y., Hayakawa, M., Haraguchi, K. et al., 2014.

Appl. Biochem. Biotechnol. 174, 869-879.

Serpi, C., Voulgaropoulos, A., Girousi, S., 2013. Electroanalysis 25, 1256-1262.

Shanmuganathan, R., Basheer, N.B., Amirthalingam, L., Muthukumar, H., Kaliaperumal, R., Shanmugam, K., 2013. J. Mol. Diagn. 15 (1), 17-26.

Sina, A.A., Carrascosa, L.G., Palanisamy, R., Rauf, S., Shiddiky, M.J.A., Trau, M., 2014a. Anal. Chem. 86 (20), 10179-10185.

Sina, A.A., Howell, S., Carrascosa, L.G., Rauf, S., Shiddiky, M.J.A., Trau, M., 2014b. Chem. Commun. 50 (86), 13153-13156.

Singer-Sam, J., LeBon, J.M., Tanguay, R.L., Riggs, A.D., 1990. Nucleic Acids Res. 18 (3), 687.

Taleat, Z., Mathwig, K., Sudhölter, E.J.R., Rassaei, L., 2015. Trac-Trends Anal. Chem. 66, 80-89.

Tanaka, K., Tainaka, K., Kamei, T., Okamoto, A., 2007. J. Am. Chem. Soc. 129, 5612-5620.

Tang, D., Liu, J., Wang, D.R., Yu, H.F., Li, Y.K., Zhang, J.Q., 2011. Clin. Invest. Med. 34 (1), 88-95.

Taylor, K.H., Kramer, R.S., Davis, J.W., Guo, J., Duff, D.J., Xu, D., et al. 2007. Cancer Res. 67 (18), 8511-8518. 
Teodoridis, J.M., Hall, J., Marsh, S., Kannall, H.D., Smyth, C., Curto, J., et al., 2005. Cancer Res. 65, 8961-8967

Topkaya, S.N., Azimzadeh, M., Ozsoz, M., 2016. Electroanalysis 28 (7), 1402-1419.

Tost, J., Gut, I.G., 2006. DNA Methylation Analysis by MALDI Mass Spectrometry. In: Meyers, R.A. (Ed.), Reviews in Cell Biology and Molecular Medicine. Wiley-VCH Verlag GmbH \& Co. KGaA, New Jersey, Volume 1, Suppliment 5, doi 10.1002/3527600906.mcb.201100025.

Tucker, K.L., 2001. Neuron 30 (3), 649-652.

Varghese, N., Mogera, U., Govindaraj, A., Das, A., Maiti, P.K., Sood, A.K., Rao, C.N., 2009. ChemPhysChem 10, $206-210$

Vertino, P.M., Yen, R.W., Gao, J., Baylin, S.B., 1996. Mol. Cell Biol. 16 (8), 4555-4565.

Wagner, M.K., Li, F., Li, J., Li, X.-F., Le, X.C., 2010. Anal. Bioanal. Chem. 397 (8), 32133224.

Wang, X., Song, Y., Song, M., Wang, Z., Li, T., Wang, H., 2009. Anal. Chem. 81 (19), 78857891.

Wang, P., Mai, Z., Dai, Z., Zou, X., 2010. Chem. Commun. 46 (41), 7781-7783.

Wang, M., Xu, Z., Chen, L., Yin, H., Ai, S., 2012. Anal. Chem. 84, 9072-9078

Wang, P., Chen, H., Tian, J., Dai, Z., Zou, X., 2013. Biosens. Bioelectron. 45, 34-39.

Wang, W-J., Li, J-J., Rui, K., Gai, P-P., Zhang, J-R., Zhu, J-J., 2015a. Anal. Chem. 87, 30193026

Wang, Y., Wee, E.J., Trau, M., 2015b. Chem. Commun. 51 (54), 10953-10956.

Wang, P., Han, P., Dong, L., Miao, X., 2015c. Electrochem. Commun. 61, 36-39.

Wang, X., Liu, X., Hou, T., Li, W., Li, F., 2015d. Sensor. Actuator B-Chem. 208, 575-580.

Wang, Y., Wee, E.J., Trau, M., 2016a. Chem. Commun. 52 (17), 3560-3563. 
Wang, L., Yu, F., Wang, F., Chen, Z., 2016b. J. Solid State Electrochem. 20 (5), 12631270.1-8.

Wee, E.J., Shiddiky, M.J.A., Brown, M.A., Trau, M., 2012. Chem. Commun. 48 (98), 1201412016.

Wee, E.J., Shiddiky, M.J.A., Trau, M., 2013. Detection DNA methylation for cancer diagnostics and prognostics, in: Shiddiky, M.J.A., Wee, E.J., Rauf, S., Trau, M. (Eds.), Microfluidics, nanotechnology and disease biomarkers for personalized medicine applications. Nova Science Publishers, Inc, New York, pp 117-131.

Wee, E.J., Ngo, T.H., Trau, M., 2015a. Clin. Eepigenetics 7 (1), 65.

Wee, E.J., Rauf, S., Shiddiky, M.J.A., Dobrovic, A., Trau, M., 2015b. Clin. Chem. 61 (1), 163-171.

Wiedmann, M., Wilson, W.J., Czajka, J., Luo, J., Barany, F., Batt, C.A., 1994. PCR Meth. Appl. 3 (4), S51-64.

Wojdacz, T.K., Dobrovic, A., 2007. Nucleic Acids Res. 35 (6), e41.

Wu, M., Kempaiah, R., Jimmy Huang, P-J., Maheshwari, V., Liu, J., 2011. Langmuir 27 (6), $2731-2738$

Wu, Y., Zhang, B., Guo, L.-H., 2013. Anal. Chem. 85 (14), 6908-6914.

Xiong, Z., Laird, P.W., 1997. Nucleic Acids Res. 25 (12), 2532-2534.

Xu, Z., Wang, M., Yin, H., Ai, S., Wang, L., Pang, J., 2013. Electrochim. Acta 112, 596602.

Xu, Y., Gao, X., Zhang, L., Chen, D., Dai, Z., Zou, X., 2016. J. Electroanal. Chem.

Yamada, H., Tanabe, K., Nishimoto, S.I-i., 2008. Org. Biomol. Chem. 6 (2), 272-277.

Yan, P.S., Chen, C.M., Shi, H., Rahmatpanah, F., Wei, S.H., Caldwell, C.W., Huang, T.H.M., 2001. Cancer Res. 61 (23), 8375-8380. 
Yanagisawa, H., Kurita, R., Yoshida, T., Kamata, T., Niwa, O., 2015. Sensor. Actuator BChem. 221, 816-822.

Yin, H., Sun, B., Zhou, Y., Wang, M., Xu, Z., Fu, Z., Ai, S., 2014. Biosens. Bioelectron. 51, 103-108.

Zhang, X., Liu, B., Dave, N., Servos, M.R., Liu, J., 2012. Langmuir 28 (49), 17053-17060.

Zhang, Y., Wang, T.H., 2012. Theranostics 2 (7), 631-654.

Zhang, X., Liu, B., Servos, M.R., Liu, J., 2013. Langmuir 29 (20), 6091-6098.

Zhang, L., Wei, M., Gao, C., Wei, W., Zhang, Y., Liu, S., 2015a. Biosens. Bioelectron. 73, 188-194.

Zhang, L., Xu, Y.-Z., Xiao, X.-F., Chen, J., Zhou, X.-Q., Zhu, W.-Y., Dai, Z., Zou, X.-Y., 2015b. Trac-Trends Anal. Chem. 72, 114-122.

Zhang, L., Liu, Y., Li, Y., Zhao, Y., Wei, W., Liu, S., 2016. Anal. Chim. Acta 933, 75-81.

Zhao, W.-W., Xu, J.-J., Chen, H.-Y., 2014. Chem. Rev. 114 (15), 7421-7441.

Zhu, J., \& Yao, X. 2009. Int. J. Biochem. Cell Biol. 41 (1), 147-154.

Zhu, B., Booth, M.A., Shepherd, P., Sheppard, A., Travas-Sejdic, J., 2015. Biosens. Bioelectron. 64, 74-80.

Figure Captions

Fig. 1. DNA methylation and its association with tumorigenesis. (i) Representation of the transfer of a methyl group to naked DNA by Dnmt3a and Dnmt3b, while Dnmt1 upholds the 
DNA methylation pattern during semiconservative replication. (ii) Representation of the changes in methylation in early periods of tumorigenesis. Reproduced from Moore et al. (2013) and Robertson (2005) with permission from Nature Publishing Group.

Fig. 2. Direct electrochemical oxidation of $5 \mathrm{mC}$. (i) Individual nucleobases and $5 \mathrm{mC}$ were cut by restriction endonuclease followed by their oxidation which produced distinct oxidation peak for $5 \mathrm{mC}$ and $\mathrm{C}$. (ii) Background-subtracted differential pulse voltametric responses from the direct oxidation of bases where $50 \mathrm{mM} 5 \mathrm{mC}$ (A) and $50 \mathrm{mM} \mathrm{C}$ (B) $50 \mathrm{mM} 5 \mathrm{mC}$ and $\mathrm{C}$ (C) $25 \mathrm{mM} \mathrm{G}$ and $\mathrm{A}$, and $50 \mathrm{mM} 5 \mathrm{mC}$ and $\mathrm{C}$ (D) were used to differentiate $5 \mathrm{mC}$ from C. (a)(d) represents the fabrication steps of the electrode where bare (a) GCE, (b) Ch/GCE, (c) MWNTs/GCE and (d) MWNTs/Ch/GCE were used. Reproduced from Kato et al. (2011) and Wang et al. (2010) with permission from with permission from The American Chemical Society and The Royal Society of Chemistry, respectively.

Fig. 3 Enzymatic reaction and amplification based electrochemical DNA methylation assays. (i) Signal-on assay, where unmethylated and methylated DNA produced two distinct redox signals in CV resulting in the activity analysis of MTase (as the different pattern of MTase activity is directly related to the distinct current changes in CV), (ii) Representation of photoelectrochemical discrimination of $\mathrm{C}$ and $5 \mathrm{mC}$ in DNA immobilized on a gold electrode and (iii) Ligase chain reaction based electrochemical assay for the detection of $5 \mathrm{mC}$. Figures (i), (ii) and (iii) are reproduced from Muren et al. (2013), Yamada et al. (2008) and Koo et al. (2014) with permission from The American Chemical Society, Royal Society of Chemistry, and Elsevier, respectively. 
Fig. 4. Schematic representations of methylation-specific ligation-detection reaction based assay for the simultaneous electrochemical detection of multiple gene-methylation loci. Reproduced from Dai et al., 2013 with permission from The Royal Society of Chemistry.

Fig. 5. Schematic of the eMethylsorb and graphene-DNA based methylation assays. Bisulphite conversion and PCR amplification processes converted methylated and unmethylated sequences sample into guanine- and adenine-enriched sequences. (i) Since DNA-gold affinity interaction follows the trend, $A>C>G>T$, the adenine-enriched unmethylated DNA leads to a larger level of adsorbed DNA on the electrode in comparison to the guanine-enriched methylated DNA. This provides less relative current for unmethylated sample due to the strong coulombic repulsion between $\left[\mathrm{Fe}(\mathrm{CN})_{6}\right]^{3-}$ and negatively charged adenine-enriched DNA strands.(ii) Since graphene -gold affinity interaction follows the trend, $\mathrm{G}>\mathrm{A}>\mathrm{C}>\mathrm{T}$, the guanine-enriched methylated DNA leads to a larger level of adsorbed DNA on the electrode in comparison to the adenine-enriched unmethylated DNA, resulting less relative current for methylated sample. Figures (i) and (ii) reproduced from Sina et al. (2014b) and Haque et al., (2016) with permission from The American Chemical Society and Elsevier, respectively. 
